УДК 740

\title{
ПСИХОЛОГИЧЕСКИЕ БАРЬЕРЫ В ИЗУЧЕНИИ ИНОСТРАННОГО ЯЗЫКА В НЕЯЗЫКОВЫХ ВУЗАХ
}

\author{
Идразова Элина Сайд-Ахмадовна \\ кандидат филологических наук, \\ доцент кафедры иностранных языков \\ Мунгашева Марина Сайдамагомедовна \\ ассистент кафедры иностранных языков \\ Чеченский государственный университет
}

\begin{abstract}
Аннотация: В данной статье рассматриваются психологические барьеры, возникающие у студентов неязыковых вузов при изучении иностранного языка, и способы их преодоления. Специфика изучения иностранного языка, как непрофильной дисциплины, предполагает главным образом развитие коммуникативных навыков. Проведенный анализ показал, что наибольшие трудности возникают в разделах языка, формирующих коммуникативную компетенцию.
\end{abstract}

Ключевые слова: психологические барьеры, иностранный язык, коммуникация, стресс, преодоление.

\section{PSYCHOLOGICAL BARRIERS IN LEARNING A FOREIGN LANGUAGE IN NON-LINGUISTIC UNIVERSITIES}

\section{Idrazova Elina Sayd-Akhmadovna Mungasheva Marina Saidamagomedovna}

\begin{abstract}
This article discusses the psychological barriers that arise in students of non-linguistic universities when learning a foreign language, and ways to overcome them. The specifics of learning a foreign language, as a non-core discipline, mainly involves the development of communication skills. The analysis showed that the greatest difficulties arise in the sections of the language that form the communicative competence.
\end{abstract}

Key words: psychological barriers, foreign language, communication, stress, overcoming. 
Согласно психологическому словарю С.Ю. Головина, психологический барьер - это психическое состояние, проявляемое как неадекватная пассивность, создающее препятствие к выполнению тех или иных действий. Проявляется обычно в деловых и личных взаимоотношениях.

Среди отечественных психологов, изучавших проблему психологических барьеров, можно выделить С. Рубинштейн, А. Леонтьев, Б.Д. Парыгин, Б. Ломов, первыми из зарубежных ученых, кто занимался исследованием данного вопроса, по праву можно считать 3. Фрейд, А. Адлер, К. Хорни, К. Юнг.

Фрейд указывал, что психологический барьер является формой психологической защиты от неприятных эмоций. Также считал, что во взаимодействии инстинктивных влечений и барьеров формируется поведение человека.

К. Юнг полагал, что, когда у человека в сознании формируется цель, в его бессознательном присутствует антицель, которая способствует срыву намеченных намерений (устремлений). Такое взаимодействие противоположных психических сил и формирует психологические барьеры.

В отечественной психологии психологический барьер рассматривается или со стороны характеристик качеств человека, или же с позиции аналитического рассмотрения видов познавательной и творческой деятельности.

Б.Д. Парыгин так определяет психологический барьер: «психологический барьер - это устойчивая установка или психический настрой личности, состояние или свойство индивида, не позволяющее реализовать духовнопсихический потенциал человека в процессе его жизнедеятельности».

Рубинштейн пишет, что любому действию свойственна противоречивость, внутренний конфликт, вызывающий напряженное эмоциональное состояние. Это состояние и выступает барьером, препятствием к достижению поставленной цели, является причиной к прекращению деятельности или менее эффективному ее выполнению.

На наш взгляд, психологический барьер - это некое эмоционально негативное состояние, возникающее при выполнении действий и препятствующее его завершению против внутренних убеждений.

Иностранный язык в неязыковых вузах изучается в первую очередь, как средство коммуникации. Коммуникативные барьеры классифицируются на несколько видов: 
1) Семантические барьеры

2) Личностные барьеры

3) Культурные барьеры

4) Фонетические барьеры

5) Социальные барьеры

6) Физические барьеры

При изучении иностранного языка, на наш взгляд, чаще всего учащиеся сталкиваются с барьерами непонимания и личностными барьерами, где проявляются:

1. Чувство страха из-за недостаточного словарного запаса в диалогической речи;

2. Раздражительность из-за непонимания смысла сообщения при аудировании;

3. Неуверенность ввиду особенностей речевого поведения;

4. Стеснительность при воспроизведении звуков;

5. Снижение мотивации или нежелание к действию из-за большого объема новой информации по всем разделам языка в ограниченное время;

6. Ощущение непреодолимости трудности из-за несовершенства восприятия ввиду несоответствия структуры иностранного и родного языков.

Как мы видим, психологический барьер при обучении иностранному языку формируется в тесной взаимосвязи учебной деятельности с эмоциями обучающегося. Иначе говоря, в формировании психологического барьера, с которым сталкиваются при изучении иностранного языка, большую роль играют личностные качества человека. Б.Д. Парыгин, определяя психологический барьер, различал внутренние барьеры личности, связанные с личностными особенностями, и внешние, к примеру, непонимание со стороны другого человека или недостаток информации. Следовательно, при изучении иностранного языка человек сталкивается с корреляцией внутренних и внешних психологических барьеров.

Самым распространенным среди психологических барьеров принято считать «страх контакта». Человек, имеющий предрасположенность к подобному психологическому барьеру, сталкивается с полным нежеланием к освоению коммуникативной компетенции дисциплины при выполнении остальных компетенций.

В психологии существует множество видов «стратегий преодоления» психологических барьеров. 
Рубинштейн различает два вида жизненной стратегии человека: ситуативную и личностную. Основная идея ситуативной стратегии - это рассчитывать на случай, удачу, везение с наименьшей личностной ответственностью и минимальными усилиями; личностная же предполагает, что человек берет всю ответственность на себя, предпринимает активные действия в жизнедеятельности.

Дроздов называет преодоление психологического барьера внутренней работой личности, направленной на активизацию внутренних ресурсов, под которыми понимается нахождение мотива деятельности и личного смысла в ней. По мнению Дроздова, в учебном процессе личность сама определяет пути и способы преодоления психологического барьера, иначе говоря, это процесс сугубо индивидуальный, требующий активной внутренней работы учащегося.

Анализ отечественных научных работ по психологии и педагогике доказывает отсутствие четко определенной стратегии и целенаправленно разработанных методик для преодоления психологических барьеров при освоении иностранного языка. [7]

На наш взгляд, в педагогическом понимании под «стратегией преодоления» психологического барьера следует понимать определенные тактики, методики и план действий со стороны педагога, и активную личностную работу со стороны обучающегося.

Для преодоления психологического барьера необходимо со стороны обучающегося:

1. Эмоциональная сфера - Формирование навыков и управление своими эмоциями, формирование адекватной самооценки.

2. Волевая сфера - Освоить навыки самоконтроля, научиться планировать учебную деятельность, развивать самодисциплину, целеустремленность.

3. Интеллектуальная сфера - Определить причины неудач, анализировать ситуацию, развивать умение слышать, воспринимать, обрабатывать информацию.

Обзор научной лит-ры (Г.М. Андреева, О.С. Булатова, А.А. Вербицкий, О.С. Гребенюк, Т.Б. Гребенюк, А. Егидес, Е.Н. Ильин, Г.А. Китайгородская, Г. Лозанов, Б.Д. Парыгин, М.И. Станкин, Т.Д. Холостова, В.А. Якунин и др.) показывает, что развитие психических сфер обучающегося повышает эффективность освоения дисциплины, чему способствует множество факторов со стороны педагога. Основными факторами в организации такого процесса, 
регулирующего психику обучающегося, выступают: эмпатия, позитивный настрой, готовность к контакту, артистизм педагога, готовность менять/пробовать методики, вербальные и невербальные средства общения, интерактивные методы обучения, игровые методы обучения, юмор.

Статистические данные проведенного анкетирования подтверждают, что основные трудности в изучении иностранного языка в большей степени возникают в освоении лексического и фонетического разделов. Из этого следует, что передача звукового образа слова и достаточный словарный запас являются главными составляющими в освоении коммуникативных навыков, говорения.

Количественное отображение данных в иерархическом порядке выглядит следующим образом:

1. Различать фразеологические обороты и идиомы $6,35 \%$.

2. Умение подобрать семантические и грамматически правильный вариант лексемы $6,25 \%$.

3. Умение грамматически согласованно сочетать слова в предложениях $6,24 \%$.

4. Умение точно интонировать $6,03 \%$.

5. Свободно употреблять слова и словосочетания для выражения своих мыслей 5,99\%.

6. Умение строить грамматически правильную речь 5,36\%.

7. Свободно понимать высказывание собеседника 5,48\%.

8. Способность к запоминанию новых слов $5,46 \%$.

9. Неспособность идентично воспроизводить звуки 5,44\%.

10. Нахождение общих грамматических форм (видовременных) 5,36\%.

11. Правильно воспринимать (распознавать) слышимый звук $5,21 \%$.

12. Умение производить мыслительные операции с языковым материалом (перевод, эссе, письмо) 5,11\%.

13. Умение вести диалогическую речь (умение синхронно воспринимать и воспроизводить речь) 5,08\%.

14. Произношение звуков идентичное оригинальному 5,06\%.

15. Умение изменять формы слов (категории) $4,94 \%$.

16. Навыки образного мышления 4,6\%.

17. Умение определять синтаксические конструкции (оборот there is, there are) $4,58 \%$.

18. Уметь составлять предложения различные по цели высказывания $3,12 \%$. 
19. Умение использовать стилистические средства - изменение порядка слов (инверсия) $3,12 \%$.

20. Разбирать предложения по членам $2,17 \%$.

Проведенный анализ позволил выявить, что такие разделы языка, как грамматика и синтаксис, требующие определенных когнитивных способностей, вызывают наименьшие затруднения. В то время как для лексического раздела, который показал наибольший процент затруднений, необходима системность, усидчивость, самодисциплина, что требует проявления волевой сферы личности. Центральную позицию в процентной градации занимает фонетический раздел языка, освоение которого вызывает наибольшие негативные чувства, такие как страх, раздражительность, неуверенность, стеснительность, требующий от обучающегося управления и контроля своими эмоциями.

Как известно, психологические особенности субъекта влияют на специфичность поведения при стрессе, в нашем случае при преодолении психологических барьеров. Так, люди, склонные к завышенным требованиям к себе, больше подвержены самокритике и, следовательно, страх ошибиться у таких людей возрастает, что мешает свободному течению процесса обучения, который предполагает на первоначальных этапах многократные ошибки. Повышенная тревожность способствует чрезмерному напряжению, что снижает эффективность учебной деятельности, повышает утомляемость, снижает работоспособность.

Преодоление психологических барьеров в изучении иностранного языка является комплексным процессом, задействующим различные качества личности.

\section{Список литературы}

1. Аблашева Е.А. Психологические барьеры в изучении иностранных языков в подростковом возрасте // Наука и образование ONLINE (Новости науки). - 2017. - URL: https://student.eeescience.ru/listing/psihologicheskie-bareryv-izuchenii-inostrannyh-yazykov-v-podrostkovom-vozraste/

2. Вербицкая Т.И. Педагогические условия преодоления психологических барьеров у студентов в процессе обучения иностранному языку. Автореф. дис. канд. пед. наук. Калининград, 2003. - 18 с.

3. Глазкова И.Я. Исследование проблемы барьеров в отечественной психологии // Вестник Таганрогского Государственного Педагогического 
Института. - 2012. - № 1c. - C. 137-142. - URL: https://cyberleninka.ru/article/n/ issledovanie-problemy-barierov-v-otechestvennoy-psihologii.

4. Лаврентьев Г.В., Лаврентьева Н.Б., Зацепина О.В. Классификация учебных барьеров и затруднений и способов их преодоления при использовании технологии организации самостоятельной работы студентов. Известия Алтайского государственного университета, 2013.

5. Манина В.А. Психолого-педагогические условия преодоления психологических барьеров деятельности. Вестник ОГУ №12 (161), 2013.

6. Сергеева А.В., Чаплыгина О.В. Проблема психологических барьеров при изучении иностранного языка // Научно-методический электронный журнал «Концепт». - 2019. - № 6 (июнь). - 0,4 п. л. - URL: http://e-koncept.ru/ 2019/192024.htm.

7. Чаплина Е.И. Стратегии преодоления психологических барьеров у студентов при изучении иностранного языка. Автореферат дис. канд. псих. наук. Курск, 2006. - 27 с. 